Biol. Stud. 2019: 13(2); 67-78 • DOI: https://doi.org/10.30970/sbi.1302.602

www.http://publications.Inu.edu.ua/journals/index.php/biology

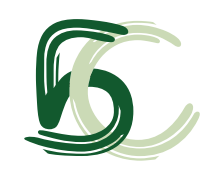

UDC: 581.526

\title{
THE VEGETATION OF "BILA SKELYA" TRACT (YAVORIV NATIONAL NATURE PARK, LVIV REGION)
}

\author{
O. T. Kuzyarin ${ }^{1}$, M. R. Hrytsyna ${ }^{2 *}$, B. V. Senchyna ${ }^{3}$, I. P. Lubynets ${ }^{4}$ \\ ${ }^{1}$ State Museum of Natural History, NAS of Ukraine, 18, Theatralna St., Lviv 79008, Ukraine \\ ${ }^{2}$ Stepan Gzhytskyj Lviv National University of Veterinary Medicine and Biotechnologies \\ 50, Pekarska St., Lviv 79010, Ukraine \\ ${ }^{3}$ Ivan Franko National University of Lviv, 41, Doroshenko St., Lviv 79000, Ukraine \\ ${ }^{4}$ Yavoriv National Nature Park, 23, Zelena St., Ivano-Frankove, Lviv Region, 81070, Ukraine \\ *Corresponding author: e-mail: hrytsynamr@/vet.edu.ua
}

Kuzyarin O.T., Hrytsyna M.R., Senchyna B.V., Lubynets I.P. The vegetation of "Bila Skelya" tract (Yavoriv National Nature Park, Lviv Region). Studia Biologica, 2019: 13(2); 67-78 • DOI: https:// doi.org/10.30970/sbi.1302.602

It was found that the formation of species of "Bila Skelya" tract in the beech forest with rocky sandy outcrops counts 127 species of higher plants, including 121 species of vascular plants and 6 epigene mosses. Syntaxonomic composition (three meadow and forest plant groups), peculiarities of their ecological-coenotic structure and sozological value of the vegetation of the tract were explored.

Floristic core of plant groups of comunity Pinus sylvestris - Anthericum ramosum Teucrium chamaedrys; comunity Pinus sylvestris - Teucrium chamaedrys - Abietinella abietina; comunity Pinus sylvestris - Anthericum ramosum - Abietinella abietina, form xerothermophilic herbaceous species distinctive for the class Trifolio-Geranietea, order Origanetalia and alliances Geranion sanguinei and Trifolion medii. Bordered on xerothermal bows, association of Dentario glandulosae-Fagetum Klika 1927 em. W. Mat. form 1964 forest vegetation of alliance Fagion sylvaticae, order Fagetalia sylvaticae, class Querco-Fagetea.

It was established that plant groups are at the stage of sylvatization and partially recreational succession followed by regressive changes in structure and species composition (depletion of species diversity). The pines overgrowth on the slope is accompanied by changes in the illumination, hydrological and salt regime of the soil (acidification), which will lead to gradual displacement of xerothermophilic and psamophilic herbaceous species and a complete replacement of meadow class groups Trifolio-Geranietea on

(C) 2019 О. T. Kuzyarin et al.; Published by the Ivan Franko National University of Lviv on behalf of Біологічні Студії / Studia Biologica. This is an Open Access article distributed under the terms of the Creative Commons Attribution License (http://www.budapestopenaccessinitiative.org/ and Creative Commons Attribution 4.0 License), which permits unrestricted reuse, distribution, and reproduction in any medium, provided the original work is properly cited.

ISSN 1996-4536 (print) • ISSN 2311-0783 (on-line) • Біологічні Студії / Studia Biologica • 2019 • Том 13/№2 • С. $67-78$ 
forest coenoses of Querco-Fagetea class. This process can be stopped only by regulating (limiting) the undergrowth of trees (by carrying out periodic log cabins).

Among the investigated species, four rare species of vascular plants from the Red Book of Ukraine were identified, in particular Botrychium lunaria (L.) Sw. (xerothermal bows), Listera ovata (L.) R. Br. (grouping of hygrophilous shrubs), Neottia nidus-avis (L.) $\mathrm{R}$. Br. and Platanthera chlorantha (L.) Rich. (beech forest). Regionally rare species from the search area that require protection in Lviv region [14] contain: Alyssum gmelinii Jord., Anemone sylvestris L. and Festuca psammophila (Hacq. Ex Celak.) Fritsch, Pulmonaria mollis Wulf. ex Hornem. The species that are located on the border of their habitat or are rare for Roztochya are also of great sozological importance: Allium montanum F. W. Schmidt, Anthericum ramosum L., Gypsophila fastigiata L., Juniperus communis $\mathrm{L}$.

Thus, in order to preserve valuable geocomplexes of "Bila Skelya" tract of 38 ha (47th quarter of the Maidan Forestry of the Starytskyj military forestry), it is recommend to transfer it to Yavoriv NNP for a permanent use.

Keywords: ecological-cenotic structure, Trifolio-Geranietea, Querco-Fagetea, species saturation, rare species

\section{INTRODUCTION}

Roztochya is a unique physically-geographical region, where two decades ago Yavoriv National Nature Park (YNNP) was created to protect valuable natural complexes whose functions, except of nature conservation, are environmental, educational and recreational investigation. An important task of the park is to study the structure and dynamics of vegetation under the influence of recreation. One of valuable geobotanical complexes of the YNNP is the rocky outcrop at the north-western edge of low humpback mountain range which extends along the left bank of the Vereshchytsya River in the vicinity of Lelehivka village. This outcrop on the slope of south-western exposition up to $5 \mathrm{~m}$ in height composed by interlayer layers of the Neogene sandstones and sands, was described as early at the end of the 19th century. In the Geological Atlas of Galicia of A.M. Lomnytskyj (Łomnicki, 1998, p. 92) [13]. Here, on the rock ledges Carpathian beech forests nearby steppe vegetation are growing on the hilly strands. At the foot of the hills, there is a pine forest and in the valley of the Vereshchytsa River there are marshes and marsh complexes on the Black Lakes. The part of the strand with detachment known as "Bila Skelya" tract is an interesting geological, geomorphological and botanical object for studying and exploring the conservation conditions of rare xerothermal settlements in the region.

In the recent years, phytocenologists have been trying to reduce vegetation phytocenotic descriptions that were accumulated for more than a decade to a single classification. This concerns the syntaxonomy of xerothermic vegetation $[6,18]$. The Ukrainian geobotanists explored the meadow-steppe vegetation of the Forest-steppe [11], northwestern Podillya [7], West Podillya, including nature monuments, the Kasov and Chortov mountains [10], "Step Masyok" tracts with fragments of the Transnistrian steppe [5], in particular. The vegetation of the crystalline outcrops of the Ukrainian shield by I.S. Kontar (2000) [9]. The vegetation syntaxonomy analysis of the Roztochya region was performed by M.I. Soroka (2008) [17] and Yavoriv NNP by M.M. Zagulsky et al., 2000) $[8,19]$.

ISSN 1996-4536 (print) • ISSN 2311-0783 (on-line) • Біологічні Студії / Studia Biologica • 2019 • Том 13/№2 • С. 67-78 
Due to the relevance of phytososological researches and the elucidation of the dynamic tendencies of vegetation, the aim of our work was to study the ecologicalcenotic structure of plant communities of "Bila Skelya" tract.

\section{MATERIALS AND METHODS}

The work study was based on the results of floristic and geobotanical searches performed during 2018 and 2019 within "Bila Skelya" tract of YNNP, located on the left bank of the river Vereshchytsya in $47^{\text {th }}$ quarter of the Maidan Forestry of the Starytskyj military forest management. The "Bila Skelya" tract is elevated, armored by limestone and sandstone section of the sloping hill with sod-slightly podzolic sandy loam in combination with sod-carbonate mid-loam soils (Organization Project..., 2011) [4]. Here is an ecological route "Lelehivka" and Ivan Franko "Ecological Path" that are visited by many pupils and students for educational purposes. Also, there are pounds used for recreation.

According to the "The project of organization...", 2011 [4], two lithologic-stratigraphic complexes are well-distinguished in the Quaternary formations in the geological structure of Yavoriv NNP territory, separated by a stratigraphic and angular incongruity: lower (Upper Cretaceous Mesozoic era) and upper (Paleogene-Neogene (the third period of the Cenozoic era). The Upper Cretaceous deposits form a "base" of modern relief, covered by a powerful surface of Paleogene-Neogene and Quaternary deposits. Paleogene (Eocene) deposits have little capacity and island (fragmentary) distribution in the park and they are recorded mainly in its north-east part. The Neogene deposits lie on the uneven blurred surface of the Upper Cretaceous and Eocene deposits and form almost continuous cover whose, the formation, occurred during the Baden (Tortonian) time.

Typical section of the main stratigraphic elements of the Lower Baden Stratum (Miocene epoch) is Mykolayiv layers formed under the conditions of extensive maritime transgression, outcrops in the neighboring area of our investigations in quarter 33 Yaniv Nature Research Branch of the YNNP [4]. The lower baden has a two-membered structure. Its lower and major part is formed by a relatively heavy (up to 60-80 m) light (white and light gray) sandy deposits composed of quartz, rarely quartz-glauconite sands. Occasionally, there are layers of poorly cemented sandstones, remnants of isolated tree trunks and seashells. The upper part of the section of the Lower Baden formations of the park (2-4 $\mathrm{m}$ thick) is characterized by the presence of layers of cemented coarse-grained limestone, which are wholly or partially composed of the remains of the limestone algae. These are Naraev groups of second or middle lithotamni horizon.

The vegetation cover of the studied area is represented mainly by tree stands and is closely related to the nature of the soil. As noted by A.M. Lomnytskyj, there were limestone prevailing, in particular on the top and at watershed surfaces - beech dominates, and on sandy soil, mainly on slopes - pine. The oak occupies an intermediate position, being a part of groups of both beech and pine forests. The appearance of the outcrop and the formation of a xerothermal settlement were probably facilitated by a road laid at the foot of Bila Skelya, since miocene deposits have long been used by local residents for various economic needs, including construction.

Collection of field material was performed by means of conventional methods - itinerary and semi-stationary. Phytocenotic descriptions and their analysis were performed on the basis of ecological-floristic classification (Brown-Blank method) [3]. For identification and comparative evaluation of vegetation units of the tract were used works of the

ISSN 1996-4536 (print) • ISSN 2311-0783 (on-line) • Біологічні Студії / Studia Biologica • 2019 • Том 13/№2 • C. 67-78 
Ukrainian $[11,16,17]$ and foreign $[14,18]$ researchers. Latin names of vascular plants are given by S.L. Mosyakin, M.M. Fedorochuk [15], bryophytes - according to modern taxonomy [2].

\section{RESULTS AND DISCUSSION}

Based on the conducted phytocenotic descriptions (Table), the floristic and syntaxonomic content of the vegetation part of "Bila Skelya" tract was analyzed covering transformed xerothermic meadows (groups 1-3) and beech forest (groups 4).

Phytocenotic characteristics of the vegetation of "Bila Skelya" tract Фітоценотична характеристика рослинності урочища “Біла Скеля"

\begin{tabular}{|c|c|c|c|c|}
\hline Description number / grouping & 1 & 2 & 3 & 4 \\
\hline Area, $\mathrm{m}^{2}$ & 300 & 300 & 100 & 500 \\
\hline Steepness, hail. $\left({ }^{\circ}\right)$ & 45 & 45 & 30 & $0-2$ \\
\hline Wooden tier (a), \% & $40-50$ & $60-75$ & $40-50$ & $95-97$ \\
\hline The height of wooden tier, $\mathrm{m}$ & $6-15$ & $6-15$ & $6-15$ & $10-40$ \\
\hline Shrubby tier (b), \% & $5-7$ & $15-20$ & $20-25$ & $5-10$ \\
\hline The height of shrubby tier, $\mathrm{m}$ & $1.5-3.5$ & $1.5-3$ & $1.5-3$ & $1.5-3$ \\
\hline Herbal tier (c), \% & $55-65$ & $30-40$ & $80-85$ & $5-10$ \\
\hline The height of Herbal tier, см: & $20-80$ & $10-90$ & $15-70$ & $10-40$ \\
\hline Mossy tier (d), \% & $5-20$ & $40-50$ & $30-40$ & $1-2$ \\
\hline Species saturation & 92 & 53 & 64 & 35 \\
\hline Abietinella abietina (d) & $2 a$ & 3 & $2 b$ & - \\
\hline Acer platanoides (a) & - & un & - & - \\
\hline Acer platanoides $(\mathrm{b}, \mathrm{c})$ & 1 & - & + & 1 \\
\hline Acer pseudoplatanus (b, c) & 1 & 1 & + & 1 \\
\hline Achillea millefolium & 1 & - & 1 & - \\
\hline Acinos arvensis & 1 & + & - & - \\
\hline Actaea spicata & - & - & - & + \\
\hline Agrostis stolonifera & un & - & - & - \\
\hline Ajuga genevensis & 1 & - & + & - \\
\hline Allium montanum & $2 m$ & 1 & - & - \\
\hline Alyssum gmelinii & 1 & + & - & - \\
\hline Anemone nemorosa & - & - & - & $2 m$ \\
\hline Anemone sylvestris & $1-2 m$ & + & + & - \\
\hline Anthericum ramosum & $2 b-3$ & $2 m$ & $2 b$ & - \\
\hline Anthyllis macrocephala & + & + & - & - \\
\hline Arabis sagittata & + & - & - & - \\
\hline Artemisia campestris & 1 & 1 & - & - \\
\hline Asplenium ruta-muraria & + & - & - & - \\
\hline Botrychium lunaria & + & - & - & - \\
\hline Brachythecium albicans (d) & - & - & $2 m$ & - \\
\hline
\end{tabular}

ISSN 1996-4536 (print) • ISSN 2311-0783 (on-line) • Біологічні Студії / Studia Biologica • 2019 • Том 13/№2 • С. 67-78 
Continued Table

Brachythecium campestre (d)

Calamagrostis epigeios

Campanula sibirica

Cardaminopsis arenosa

Carex digitata

Carex hirta

Carpinus betulus (all)

Carpinus betulus (b, c)

Centaurea stoebe

Cerasus avium (b, c)

Chaerophyllum temulum

Chamaecytisus ruthenicus

Clinopodium vulgare

Convallaria majalis

Corylus avellana (b)

Crataegus monogyna (b, c)

Cruciata glabra

Daphne mezereum (c)

Dianthus carthusianorum

Dryopteris filix-mas

Elytrigia repens

Equisetum arvense

Erigeron acris

Euonymus europaea (c)

Euonymus verrucosa (b, c)

Eupatorium cannabinum

Euphorbia angulata

Euphorbia cyparissias

Fagus sylvatica (al)

Fagus sylvatica (b, c)

Festuca psammophila

Fragaria vesca

Frangula alnus (b, c)

Galium boreale

Galium intermedium

Galium boreale

Galium odoratum

Galium verum

Galium wirtgenii

Geranium robertianum

Helianthemum ovatum

\section{$-$}

1

1

1

1

$+$

$-$

\section{$+$}

1



\section{-}

1

1

1

1

\section{$+$}

1

$-$

1

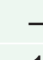

1

1

1

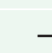

\section{$+$}

$+$

$2 a$

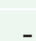

\section{$-$}

- $\quad-$

1

1

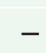

1

\section{1}

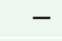

\section{$-$}

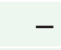

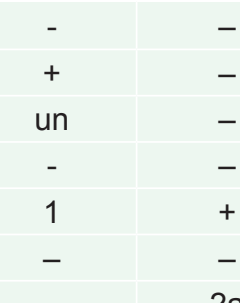

$-$ 
Continued Table

Hieracium silvestre

Hylotelephium maximum

Hypericum perforatum

Isopyrum thalictroides

Juniperus communis (c)

Knautia arvensis

Lathyrus vernus

Leontodon hispidus

Luzula pilosa

Majanthemum bifolium

Medicago falcata

Medicago lupulina

Melica nutans

Milium effusum

Mycelis muralis

Neottia nidus-avis

Padus avium (c)

Peucedanum oreoselinum

Phalacroloma annuum

Picea abies (c)

Pilosella officinarum

Pilosella praealta

Pinus sylvestris (al)

Pinus sylvestris (b, c)

Plagiomnium undulatum (d)

Plantago lanceolata

Platanthera chlorantha

Poa compressa

Polygala comosa

Polygonatum multiflorum

Polygonatum odoratum

Potentilla arenaria

Primula veris

Pulmonaria mollis

Pyrus communis (c)

Quercus robur (all)

Quercus robur (b, c)

Quercus rubra (b, c)

Ranunculus polyanthemos

Rhamnus cathartica (b, c)

Rhytidiadelphus triquetrus (d)

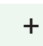

1

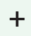

$-$

$+$

1

$-$

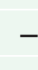

-

$-$

1

$+$

$+$

$-$

\section{$-$}

$-$

$-$

1

un

\section{-}

1

1

3

1

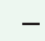

un

-

\section{$-$}

1

-

1

$2 \mathrm{~m}$

1

1

un

$-$
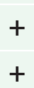

$+$

$+$

$-$
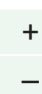

$\begin{array}{cc}- & - \\ \text { un } & +\end{array}$

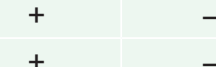

1

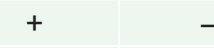

$+\quad+$

$+\quad 2 \mathrm{~m}$

$2 \mathrm{~m}$

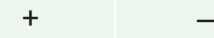

$\begin{array}{ll}+ & 1\end{array}$

- +

- $\quad+$

- $\quad+$

- 2a

1 -

-

un -

- $\quad-$

$-$

2b-3

1

$\begin{array}{ll}1 & 1\end{array}$

-

- $\quad+$

1

-

$\begin{array}{ll}- & 1\end{array}$

-

1

-

$+$

- $\quad-$

-

- $\quad-$

$+\quad+$

$+$

- $\quad-$ 
Rosa sp. (b)

Rubus caesius (c)

Rubus hirtus (c)

Salix caprea (all, b)

Salix cinerea (b)

Salix purpurea (b)

Scabiosa ochroleuca

Securigera varia

Sedum acre

Silene nutans

Solidago canadensis

Solidago virgaurea

Sorbus aucuparia (b, c)

Swida sanguinea (b, c)

Taraxacum officinale

Teucrium chamaedrys

Thesium linophyllon

Thuidium assimile (d)

un

-

$-$

$+$

+ un

un

un

1

Thymus serpyllum

Veronica spicata

Viburnum opulus (c)

Vicia sylvatica

Vincetoxicum hirundinaria

Viola hirta

Viola reichenbachiana

\begin{tabular}{c|c|c}
\hline- & - & - \\
- & + & - \\
- & + & - \\
\hline un & - & - \\
- & - & - \\
\hline- & - & - \\
1 & + & - \\
1 & 1 & - \\
\hline 1 & - & - \\
\hline 1 & + & - \\
\hline- & - & - \\
\hline- & + & 1 \\
\hline+ & + & - \\
\hline+ & 1 & - \\
\hline- & 1 & - \\
\hline $2 a$ & $2 m$ & - \\
\hline- & + & - \\
\hline- & - & - \\
\hline 1 & + & - \\
\hline- & - & - \\
\hline- & + & + \\
\hline- & + & - \\
\hline 1 & 1 & - \\
\hline+ & + & - \\
\hline & - & - \\
\hline
\end{tabular}

Conditional designation: Herbal groups: 1 - com. Pinus sylvestris - Anthericum ramosum - Teucrium chamaedrys; 2 - com. Pinus sylvestris - Teucrium chamaedrys - Abietinella abietina; 3 - com. Pinus sylvestris - Anthericum ramosum - Abietinella abietina; 4 - ass. Dentario glandulosae-Fagetum. Participation of plants on a modified scale Brown-Blanche: un - one individual; + - 2-5 individ. cov.<5\%; $1-650$ individ. cov. $<5 \% ; 2 \mathrm{~m}->50$ individ. cov. $<5 \% ; 2 \mathrm{a}-\operatorname{cov} .5-15 \%$ regardless of the number of individuals; $2 \mathrm{~b}-\mathrm{cov}$. $16-25 \%$; 3 - cov. 26-50 \%; 4 - cov. 51-75 \%; 5 - cov. 76-100\%

Умовні позначення: Рослинні угруповання: 1 - com. Pinus sylvestris - Anthericum ramosum - Teucrium chamaedrys; 2 - com. Pinus sylvestris - Teucrium chamaedrys - Abietinella abietina; 3 - com. Pinus sylvestris - Anthericum ramosum - Abietinella abietina; 4 - ass. Dentario glandulosae-Fagetum. Участь рослин за модифрікованою шкалою Браун-Бланке: un - одна особина; + - 2-5 особин, покр. <5 \%; 1 6-50 особин, покр. < 5 \%; 2m - > 50 особин, покр. < 5 \%; 2а - покр. 5-15 \% незалежно від кількості особин; 2b - покр. 16-25 \%; 3 - покр. 26-50 \%; 4 - покр. 51-75 \%; 5 - покр. 76-100 \%

The most sozological value among them is relatively rare in Roztochya xerothermic meadows of the Trifolio-Geranietea class identified by us on the level of basal groups close in floral composition, in particular: comunity Pinus sylvestris - Anthericum ramosum - Teucrium chamaedrys; comunity Pinus sylvestris - Teucrium chamaedrys Abietinella abietina; comunity Pinus sylvestris - Anthericum ramosum - Abietinella abietina. A plot of these bows with a young sparse tree on sandy-rocky outcrops (Lower Baden sandstone and sand) covers the south-western slope (30-45 ${ }^{\circ}$ steepness) of the 
"Bila Skelya" tract. In general, the area of the plot is about 0.1 ha. Its lower part is bordered by groups of hygrophilous shrubs and trees (Salix cinerea, S. aurita, Frangula alnus, Alnus glutinosa etc.) class Alnetea glutinosae Br.-Bl. et R. Tx. 1943. Instead, xerothermal meadows are replaced by forest communities of the order on the sides and on the closet top of the hump. Fagetalia sylvaticae Pawl. 1928 class Querco-Fagetea Br.-BI. et Vlieger in Vlieger 1937 (see Table).

Specific ecotope conditions of the investigated xerothermic meadows, including geological, geomorphological and soil-hydrological, and their marginal location determine their rich floral composition and the coenotic role of individual species. Specific saturation of groups ranges from 53 to 92 species of higher plants (vascular and bryophytes) within three descriptive areas.

The studied group are marked by a relatively complex four-tiered vertical structure (with wood, shrub, grass and mossy tiers). In the rarefied (40-75\%) tree stand Pinus sylvestris is dominated about 15-25 years old and 8-12 (15) $\mathrm{m}$. tall. The diameter of tree trunks ranges from 5 to $25 \mathrm{~cm}$.

Poorly developed (5-25\%) shrubby tier consists of undergrowth of trees (Acer platanoides, A. pseudoplatanus, Carpinus betulus, Fagus sylvatica, Pinus sylvestris, Quercus robur, Quercus borealis and others) and bushes of predominantly regenerative age (Corylus avellana, Euonymus verrucosa, Frangula alnus, Rhamnus cathartica, Swida sanguinea etc.).

The total projection coverage of sward in the most illuminated areas reaches $85 \%$. Such xeromesophytes are dominant, as Anthericum ramosum (to $40 \%$ ) and Teucrium chamaedrys (to $25 \%$ ). The herbaceous floral nucleus is formed by class-specific xerothermophilic species Trifolio-Geranietea, order Origanetalia and alliances Geranion sanguinei and Trifolion medii (Anemone sylvestris, Anthericum ramosum, Clinopodium vulgare, Coronilla varia, Galium verum, Galium wirtgenii, Knautia arvensis, Medicago falcata, Peucedanum oreoselinum, Polygonatum odoratum, Silene nutans, Vicia sylvatica, Vincetoxicum hirundinaria, Viola hirta). Xerophilic meadow species of the class are partially represented among other species in the herbaceous composition FestucoBrometea Br.-BI. et R.Tx. 1943 (Ajuga genevensis, Acinos arvensis, Arabis sagittata, Artemisia campestris, Dianthus carthusianorum, Euphorbia cyparissias, Helianthemum ovatum, Poa compressa, Scabiosa ochroleuca, Veronica spicata), order Festucetalia valesiacae Br.-BI. et R.Tx. 1943 (Campanula sibirica, Potentilla arenaria, Thesium linophyllon), as to a lesser extent, psamophilic species of the Koelerio glaucae-corynephoretea canescentis class and Koelerion glaucae (Alyssum gmelini, Brachythecium albicans, Centhaurea rhenana, Festuca psammophila, Sedum acre, Thymus serpyllum) union. For a long time it was mistakenly believed that Festuca pallens was growing on the White Rock. Subsequently, it was proved that the population Festuca psammophila is represented here and its place of growth is easternmost in Europe and needs protection at the national level [1]. In the most illuminated area, this species are represented as a co-dominant, forming a projection coverage of about $15 \%$.

A number of forest species characteristic of the class were also recorded among the asectors Querco-Fagetea (Acer platanoides, Carex digitata, Carpinus betulus, Corylus avellana, Euonymus verrucosa, Fagus sylvatica, Lathyrus vernus, Melica nutans, Isopyrum thalictroides etc.). They are spread from adjacent forest phytocoenoses and are indicators of active sylvatic succession. In addition, the locality of the petrophilic species was detected within a separate grouping, Asplenium ruta-muraria, that is dated

ISSN 1996-4536 (print) • ISSN 2311-0783 (on-line) • Біологічні Студії / Studia Biologica • 2019 • Том 13/№2 • С. 67-78 
to sandstone outcrops. Numerous synanthropes, in particular Elytrigia repens, Equisetum arvense, Solidago canadensis, Stenactis annua and Taraxacum officinale aggr. are mainly focused on the most disturbed areas. The mossy tier is maximally developed (40-50 \%) in shaded and relatively sloping areas. Its components are epigene xeromesophilic species (Abietinella abietina (Hedw.) M.Fleisch., Brachythecium albicans (Hedw.) Schimp., Brachythecium campestre (Müll.Hal.) Schimp. тa Rhytidiadelphus triquetrus (Hedw.) Warnst.).

Based on the analysis of the floristic composition and coenotic structure of the investigated xerothermic bows, we concluded that the formation of these groups occurred in the nineteenth century and is obviously related to the laying of the road and the functioning of the elemental quarry (sandstone mining). At the present stage, these phytocoenoses are intensively overgrown with forest species that threatens their further existence.

Beech forest grouping (association Dentario glandulosae-Fagetum) (see table), located on top of the hump and border with xerothermal bows, belongs to the alliance Fagion sylvaticae, order Fagetalia sylvaticae, class Querco-Fagetea. It accomplies with the Dentario glandulosae-Fagetum Klika $1927 \mathrm{em}$. W. Mat. 1964 association by the ecological-cenotical structure. Its sozological value is determined primarily by the presence of rare species such as Neottia nidus-avis and Platanthera chlorantha, listed in the Red Book of Ukraine.

In the first tier, Fagus sylvatica dominates with quite closed tree stands (85-90\%). The second tier of tree stands forms Carpinus betulus (10-15\%). Slightly expressed (5-10\%) shrub layer is represented by common species of deciduous and mixed forests, mainly with a reduced vitality (Corylus avellana, Euonymus europaea, E. verrucosa, Padus avium, etc.) and healthy undergrowth of forest species (Acer platanoides, A. pseudoplatanus, Carpinus betulus and Quercus borealis).

Herbal cover (5-10\%) is formed by class-specific non-moral species Querco-Fagetea (Actaea spicata, Anemone nemorosa, Carex digitata, Convallaria majalis, Galium odoratum, Lathyrus vernus, Melica nutans, Milium effusum, Mycelis muralis, Polygonatum multiflorum, Viola reichenbachiana etc.). A ground moss cover of the group which involves trivial forest species Plagiomnium undulatum does not exceed 1-2 \%.

Within the "Bila Skelya" tract, four rare species of vascular plants from the Red Book of Ukraine grow, in particular Botrychium lunaria (L.) Sw. (xerothermal bows), Listera ovata (L.) R. Br. (grouping of hygrophilous shrubs), Neottia nidus-avis (L.) R. Br. and Platanthera chlorantha (L.) Rich. (beech forest). Regionally rare species from the investigated area that require protection in Lviv region [14] include: Alyssum gmelinii Jord., Anemone sylvestris L., Festuca psammophila (Hacq. Ex Celak.) Fritsch, Pulmonaria mollis Wulf. ex Hornem. Species located at the edge of their range or are rare for Roztochya, also have sozological significance: Allium montanum F.W. Schmidt, Anthericum ramosum L., Gypsophila fastigiata L., Juniperus communis L.

\section{CONCLUSIONS}

It was found that species diversity of a large part of the "Bila Skelya" tract on the slope of the south-western exposure of the sandy mountain counts 127 species of higher plants, including 121 species of vascular plants and 6 epigene mosses.

Syntaxonomic composition is clarified (one association - Dentario glandulosaeFagetum and three basal groups: Pinus sylvestris - Anthericum ramosum - Teucrium

ISSN 1996-4536 (print) • ISSN 2311-0783 (on-line) • Біологічні Студії / Studia Biologica • 2019 • Том 13/№2 • C. 67-78 
chamaedrys; Pinus sylvestris - Teucrium chamaedrys - Abietinella abietina; Pinus sylvestris - Anthericum ramosum - Abietinella abietina), its peculiarities of ecologicalcenotic structure and sozological value of vegetation of the tract as well.

It has been established that plant grouping is at the stage of sylvatization and partially recreational succession with subsequent regressive changes in structure and species composition (impoverishment of species diversity).

The pines overgrowth on the slope is accompanied by changes in the illumination, hydrological and salt regime of the soil (acidification), which will lead to the gradual displacement of xerothermophilic and psamophilous herbaceous species and the complete replacement of xerothermic meadow groups class Trifolio-Geranietea on QuencoFagetea forest coenoses. This process can be stopped only by regulating (limiting) the undergrowth of trees (by carrying out periodic sanitary cabins).

Four species registered in the Red Book and four regionally rare species grow in factions. As many species are found here at the border of the range and are rare for Roztochya.

Thus, to save valuable natural complexes of the "Bila Skelya" tract whose area is 38 hectares (47th quarter of the Maidan Forestry of the Starytskyj military forestry), we recommend its transferring to the Yavoriv NNP for a permanent use.

1. Bednarska I. Festuca glauca agg. species in the flora of Ukraine. Visnyk of L'viv Univ. Biology Series. 2003; 33: 27-41. (In Ukrainian)

[Google Scolar]

2. Boiko M.F. A Checklist of Bryobionta of Ukraine. Kherson: Ailant, 2008. 232 p. (In Ukrainian) [Google Scholar]

3. Braun-Blanquet J. Pflanzensoziologie, Grundzüge der Vegetationskunde. 3rd Edition, Springer-Verlag, Berlin, 1964. $631 \mathrm{p}$.

[http://dx.doi.org/10.1007/978-3-7091-8110-2]

4. Brusak V., Rovenchak I., Vlakh M., Bairak G., Shuber P., Senchina B., Gorishniy P., Kipach F., Gorban I., Krichevska D., Moskalyuk K., Blagodir S., Zinko Y., Karpets Y., Maidansky M., Shevchuk O., Blagitka M. The project of the organization of the Yavoriv NPP territory, protection, reproduction and recreational use of its natural complexes and objects. Lviv: Ivan Franko National University, 2011. 452 p. (In Ukrainian)

5. Budzhak V.V., Korotchenko I.A., Tokaryuk A.I., Chorney I.I. Geobotanic description of vegetation natural reserves „Step Masok”. Biology systems, 2013; 5(2): 235-248. (In Ukrainian) [Google Scolar]

6. Chytry M., Rafajova M. Czech National Phytosociological Database: basic statistics of the available vegetation-plot data. Preslia, 2003; 75: 1-15.

7. Didukh Ja. P., Korotchenko I.A. Xerothermic vegetation of North-western Podolia. Visnyk of L'viv. Univ. Biology Series, 2003; 34: 82-91. (In Ukrainian) [Google Scholar]

8. Hrytsyna M. R. Analysis of synantropic flora of Yavoriv National Nature Park. Studia Biologica, 2015: 9(1); 163-176. (In Ukrainian) [DOI: https://doi.org/10.30970/sbi.0901.394; Google Scholar]

9. Kontar I.S. Dynamics of plant cover of crystal rock outcrops of forest and forest-steppe zones of Ukraine. Ukr. Botan. Journ., 2000; 57(6): 676-683. (In Ukrainian) [Google Scholar]

10. Kukovitza G.S., Diduch Ya.P., Shelyag-Sosonko Yu.R., Abduloeva O.S. Syntaxonomy of meadow steppes as a restricted natural territory the republican significance (Kasova, Chortova). Ukr. Phytosoc. Col. Ser. A, 1998; 2(11); 42-61. (In Ukrainian)

ISSN 1996-4536 (print) • ISSN 2311-0783 (on-line) • Біологічні Студії / Studia Biologica • 2019 • Том 13/№2 • С. 67-78 
11. Kuzemko A. Dry grasslands on sandy soils in the forest and forest-steppe zones of the plains region of Ukraine: present state of syntaxonomy. Tuexenia, 2009; 29: 369-390. [Google Scholar]

12. List of plant species requiring protection within the Lviv region but not included in the Red Data Book of Ukraine. (In Ukrainian)

13. Łomnicki A.M. Atlas geologiczny Galicyi: Tekst do z. 10, cz. 2. Kraków, 1998. 167 p.

14. Matuszkiewicz W. Przewodnik do oznaczania zborowisk roślinnych Polski. Wyd. 3-ie. Warszawa: Wyd-wo Naukove PWN, PL, 2008. 537 p. [Google Scholar]

15. Mosyakin S.L., Fedoronchuk M.M. Vascular Plants of Ukraine. A Nomenclatural Checklist. Kyiv, 1999. 346 p.

[Google Scholar]

16. Solomakha V.A. Syntaxonomy of the vegetation Ukraine. Third approximation. Kyiv: Phytosociocentre, 2008. 296. (In Ukrainian) [Google Scholar]

17. Soroka M.L. Vegetation of the Ukrainian Rostochia: Monograph. Lviv: Publishing House "Swit", 2008: 434. (In Ukrainian) [Google Scholar]

18. Willner W., Kuzemko A., Dengler J., Chytry M. at al. A higher-level classification of the Pannonian and western Pontic steppe grasslands (Central and Eastern Europe). Applied Vegetation Science, 2017; 20(1): 143-158. [https://doi.org/10.1111/avsc.12265; Google Scholar]

19. Zagulsky M.M., Kuchinskaya I.V., Maidansky M.A. Sozological assessment of the territory of the Yavorivsky National Nature Park. Challenges and Prospects for the Development of Conservation Objects in Roztoche: Materials from Int. Scientific and Practical Conference. Lviv: Logos, 2000: 150-152. (In Ukrainian)

\title{
РОСЛИННІСТЬ "УРОЧИЩА БІЛА СКЕЛЯ" (ЯВОРІВСЬКИЙ НАЦІОНАЛЬНИЙ ПРИРОДНИЙ ПАРК, ЛЬВІВСЬКА ОБЛАСТЬ)
}

\author{
О. Т. Кузярін ${ }^{1}$, М. Р. Грицина ${ }^{2 *}$, Б. В. Сенчина ${ }^{3}$, І. П. Любинець \\ ${ }^{1}$ Державний природознавчий музей НАН України, вул. Театральна, 18, Львів 79008, Україна \\ 2 Львівський національний університет ветеринарної медицини та біотехнологій \\ імені С.3. Гжицького, вул. Пекарська, 50, Львів 79010, Україна \\ ${ }^{3}$ Львівський національний університет імені Івана Франка \\ вул. П. Дорошенка, 41, Львів 79000, Україна \\ ${ }^{4}$ Яворівський національний природний парк \\ вул. Зелена, 23, смт Івано-Франкове, Львівська обл. 81070, Україна \\ Кореспондуючий автор: e-mail: hrytsynamr@/vet.edu.ua
}

Унаслідок проведених досліджень урочища “Біла скеля" в ділянці букового лісу зі скельними піщаними виступами з'ясовано синтаксономічний склад рослинності (три угруповання трансформованих ксеротермних лук і одна асоціація типового букового лісу), особливості еколого-ценотичної структури та созологічну цінність рослинності урочища. Встановлено, що видове різноманіття налічує 127 видів вищих рослин, зокрема, 121 вид судинних рослин і шість - епігейних мохів.

Флористичне ядро маргінальних лучних угруповань класу Trifolio-Geranietea (com. Pinus sylvestris - Anthericum ramosum - Teucrium chamaedrys; com. Pinus sylvestris - Teucrium chamaedrys - Abietinella abietina; com. Pinus sylvestris - Anthericum 
ramosum - Abietinella abietina) формують ксеротермофільні види, характерні для класу, порядку Origanetalia та союзів Geranion sanguinei і Trifolion medii. Лісова рослинність урочища представлена асоціацією Dentario glandulosae-Fagetum Klika 1927 em. W. Mat. 1964 союзу Fagion sylvaticae порядку Fagetalia sylvaticae класу Querco-Fagetea.

Встановлено, що рослинні угруповання перебувають на стадії сильватизації та частково рекреаційної сукцесії з подальшими регресивними змінами структури й видового складу (збіднення видового різноманіття). Заростання схилу сосною супроводжується насамперед змінами режиму освітлення, гідрологічного та сольового режиму ґрунту (підкислення), що в майбутньому призведе до поступового витіснення ксеротермофрільних і псамофрільних трав'яних видів та повної заміни лучних угруповань класу Trifolio-Geranietea на лісові ценози класу Querco-Fagetea. Цей процес можна призупинити лише регулюванням (обмеженням) підросту дерев (проведенням періодичних санітарних зрубів).

Серед досліджених видів виявлено чотири раритетних види судинних рослин із Червоної книги України, зокрема, Botrychium lunaria (L.) Sw. (ксеротермні луки), Listera ovata (L.) R. Br. (угруповання гігрофрільних чагарників), Neottia nidus-avis (L.) R. Br. та Platanthera chlorantha (L.) Rich. (буковий ліс). До регіонально рідкісних видів із території дослідження, що потребують охорони у Львівській області, належать: Alyssum gmelinii Jord., Anemone sylvestris L., Festuca psammophila (Hacq. ex Čelak.) Fritsch, Pulmonaria mollis Wulf. ex Hornem., Sedum maximum (L.) Hoffm. (Hylotelephium maximum (L.) Holub). Созологічну значимість мають також види, що перебувають тут на межі свого ареалу або $є$ рідкісними для Розточчя: Allium montanum F. W. Schmidt, Anthericum ramosum L., Gypsophila fastigiata L., Juniperus communis L.

3 метою збереження цінних геокомплексів урочища “Біла скеля" площею 38 га (47 квартал Майданського лісництва Старицького військового лісгоспу) рекомендовано передати його в постійне користування Яворівському НПП.

Ключові слова: рослинність, еколого-ценотична структура, Trifolio-Geranietea, Querco-Fagetea, видова насиченість, фрітосозологія, раритетні види, Яворівський НПП

Одержано: 15.10 .2019

ISSN 1996-4536 (print) • ISSN 2311-0783 (on-line) • Біологічні Студії / Studia Biologica • 2019 • Том 13/№2 • С. 67-78 